\title{
Nursing Comiittee to Coping with COVID-19 in Bahia
}

\author{
Comitê de Enfermagem para Enfrentamento da COVID-19 na Bahia \\ Comité de Enfermería para hacer frente a COVID 19 en Bahía
}

Tatiane Araújo -dos -Santos' ORCID: 0000-0003-0747-0649

Handerson Silva Santos'

ORCID: 0000-0002-4324-8888

Mariana de Almeida Moraes

ORCID: 0000-0002-0581-974X

Fernanda Carneiro Mussi'

ORCID: 0000-0003-0692-5912

'Universidade Federal da Bahia. Salvador, Bahia, Brazil.

How to cite this article:

Araújo-dos-Santos TA, Santos HS, Moraes MA, Mussi FC.

Nursing Comiittee to Coping with COVID-19 in Bahia. Rev Bras Enferm. 2020;73(Suppl 2):e20200469. doi: http://dx.doi.org/10.1590/0034-7167-2020-0469

Corresponding author:

Tatiane Araújo dos Santos

E-mail: tatianearaujosantos@yahoo.com.br

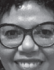

$\begin{array}{r}\text { EDITOR IN CHIEF: Dulce Barbosa } \\ \text { ASSOCIATE EDITOR: Ana Fátima Fernandes } \\ \hline \text { Submission: 05-06-2020 Approval: 06-26-2020 }\end{array}$

\begin{abstract}
Objective: To report the experience of the Nursing Committee for Coping with COVID-19 in Bahia. Methods: The experience report describes motivation, objectives, representatives, organization, working groups, activities and impact of the Committee actions. Results: The Committee consists of educational institutions and class representation. It accepts demands, questions and complaints from nursing workers, acts in favor of safe care and inspection of health and safety conditions at work. Five working groups and six technical support groups were formed. These groups address Communication, Review of Health Services Contingency Plans, Assistance to Long-Term Institutions, Epidemiology and External Activities. An Instagram account was created for quick and reliable access to information, and also an email to meet demands and monitor COVID-19 cases. Conclusion: The results of the Committee work contribute to guide, support, value and defend nursing workers in coping with COVID-19 Descriptors: Professionals' Committee; Nursing; Pandemic; Coronavirus; Intersectoral Collaboration.
\end{abstract}

\section{RESUMO}

Objetivo: Relatar a experiência do Comitê de Enfermagem para Enfrentamento da COVID-19 na Bahia. Métodos: O relato de experiência descreve motivação, objetivos, representantes, organização, grupos de trabalhos, atividades e impacto das ações do Comitê. Resultados: O Comitê é formado por instituições de ensino e representação de classe. Acolhe demandas, dúvidas e denúncias de trabalhadoras/es em enfermagem, age em prol do cuidado seguro e da fiscalização das condições de saúde e segurança no trabalho. Cinco grupos de trabalho e seis de suporte técnico foram formados. Esses grupos dirigem-se a Comunicação, Revisão de Planos de Contingência de Serviços de Saúde, Assessoria às Instituições de Longa Permanência, Epidemiologia e Atividades Externas. Criou-se conta no instagram, para acesso rápido e confiável à informação, e e-mail, para acolher demandas e monitorar casos da COVID-19. Conclusão: Os resultados do trabalho do Comitê contribuem para orientar, apoiar, valorizar e defender trabalhadoras/es em enfermagem no enfrentamento da COVID-19.

Descritores: Comitê de Profissionais; Enfermagem; Pandemia; Coronavírus; Colaboração Intersetorial.

\section{RESUMEN}

Objetivo: Informar sobre la experiencia del Comité de Enfermería de Bahía en su combate contra la COVID-19. Métodos: El informe describe la motivación, los objetivos, los representantes, la organización, los grupos de trabajo, las actividades y el impacto de las acciones del Comité. Resultados: El Comité está formado por instituciones educativas y por representación de clases. Recibe demandas, dudas y denuncias de los trabajadores de enfermería, actúa a favor del cuidado seguro y de la supervisión de las condiciones de salud y seguridad laboral. Se formaron cinco grupos de trabajo y seis grupos de apoyo técnico para actuar en la Comunicación, la Revisión de los Planes de Contingencia de los Servicios Sanitarios, el Asesoramiento de las Instituciones de Permanencia Prolongada, la Epidemiología y las Actividades Externas. Se creó una cuenta en Instagram de acceso rápido y de información confiable y un correo electrónico para organizar las demandas y supervisar los casos de COVID-19. Conclusión: Los resultados de la labor del Comité contribuyen a orientar, apoyar, valorar y defender a los trabajadores de enfermería durante la lucha contra la COVID-19. Descriptores: Comité de Profesionales; Enfermería; Pandemias; Coronavirus; Colaboración Intersectorial. 


\section{INTRODUCTION}

SARS-CoV-2 infection started in December 2019 in Wuhan province, China, and it has spread worldwide in 2020(1). Coronavirus belongs to the Coronaviridae family and causes a respiratory disease named COVID-19(1). On January 30, 2020, the World Health Organization stated that the Coronavirus outbreak constituted a Public Health Emergency of International Concern (ESPII) and, on March $11^{\text {th }}, 2020$, the pandemic was decreed ${ }^{(1)}$.

The COVID-19 pandemic is not the first one that humanity has faced in its history. However, it has been occurring at a time when the world is in an environmental, humanitarian, economic and production crisis, due to wars and its refugees. In the context of Latin America, after a decade of economic and social development, from 2015 onwards, there has been an increase in poverty, a worsening of labor market indicators and a reduction in income inequality ${ }^{(2)}$. In Brazil, there are 13 million people living in slums, having difficulties with basic sanitation and there is also an increase in informal employment, added to this panorama ${ }^{(3)}$.

Thus, considering the socioeconomic inequalities in the current context, there is a need to implement and consolidate universal, public and free Health Systems that guarantee health care, risk and damage prevention actions and health surveillance. It is worth mentioning that, in recent years, public and universal Health Systems have been under attack, and their financial resources have been withheld because of the neoliberal austerity. In the face of the pandemic, this logic fails and the importance of the State as the main inducer of health and social security policies that protect the population is noted.

In Brazil, Constitutional Amendment 95 (CA 95) ${ }^{(4)}$ removed and limited public investments for 20 years. As a result, the Unified Health System - Sistema Único de Saúde (SUS) and Public Universities, the largest producers of research, development and innovation in the country, were affected in their ability to meet social needs. We are facing a pandemic with a weakened SUS, however, SUS has been the protagonist for the containment of the pathogen and for the care of people infected by the Coronavirus. Likewise, Brazilian universities and public research centers have emerged with the quick genetic mapping of the SARS-CoV-2 virus, as well as in the production of knowledge and inputs for health services.

During the pandemic, it is possible to observe, in different countries, the centrality and the relevance of the care provided by health workers to people with COVID-19. Among them, nursing workers stand out, since they are on the front line in the care of these people, twenty-four hours a day ${ }^{(5)}$.

As it is a highly transmissible virus ${ }^{(6)}$, it is known that nursing workers, due to the care nature of their work, are vulnerable to contamination by SARS-CoV-2, especially if their working and security conditions are precarious ${ }^{(7)}$. It is necessary to remember that before the pandemic, nursing workers had already been facing precarious work, evidenced by the intensity and precarious work conditions, no guarantee of their rights and undersizing ${ }^{(7)}$, which, at this moment, becomes more serious.

Until April 28 $8^{\text {th }}, 2020$, the Federal Nursing Council (COFEN) had registered 1700 confirmed cases and 50 deaths by COVID-19 among nursing workers in the country ${ }^{(8)}$.

In the face of this scenario, it is necessary to create initiatives that meet demands, questions and complaints of the workers, while contributing to safe care, as well as to the inspection of health and safety conditions at work. Thus, entities in the nursing area came together and created the Nursing Committee for Coping with COVID-19 in Bahia.

\section{OBJECTIVE}

To report the experience of the Nursing Committee for Coping with COVID-19 in Bahia.

\section{METHODS}

This is an experience report, with a descriptive approach, on the creation and work developed by the Nursing Committee for Coping with COVID-19 in Bahia, created on March 20, 2020, in Salvador, Bahia.

This Committee comprises: the Brazilian Nursing Association Bahia section (ABEn Bahia), the Regional Nursing Council in Bahia (Coren Bahia), the Nursing School of the Federal University of Bahia (EEUFBA), the Nurses Union of the State of Bahia (SEEB), Health Workers Union of the State of Bahia (Sindsaude Bahia) and Intermunicipal Union of Nursing Technicians, Labor Nursing Technicians and Clinical Pathology Technicians of the State of Bahia (Sintefem).

This experience report describes the motivation for creating the Committee, its objectives, organization and working groups. It also describes the flows and activities performed by the several working groups and the results of the work carried out from March $20^{\text {th }}$ to April $29^{\text {th }}, 2020$.

\section{RESULTS}

\section{Motivation and objective of the Committee}

The motivation to create the Committee came with the perception ofEEUFBA professors, the fear experienced by nursing workers, who felt they had little support, and several questions about the pandemic and how to cope with it. In addition, professors felt the need to take contributions from science to effectively support care practices.

The Committee objective is to guide, support and defend nurses, nursing technicians and assistants, considering that they are on the front line of health care and that, according to the WHO, correspond to $59 \%$ of health professionals ${ }^{(9)}$. In Brazil, they predominantly occupy jobs within the scope of SUS ${ }^{(10)}$.

\section{Organization of working groups}

The Committee is organized into a Coordinating Group (CG), five Working Groups (WG) and six Technical Support Groups (TSG). Each working group has coordinators who are responsible for meeting the demands made by the CG. All people involved in the work of the Committee are volunteers.

The five WG have specific purposes, whose activities and composition are described below:

1. Coordinating Group: formed by the directors of the entities that compose the Committee. Responsible for articulation with Health Departments, Public Ministry, Public Ministry of Labor, Worker's Health Surveillance, among other bodies of interest 
to the Committee actions. It also coordinates the other working groups and approves the pieces of communication produced.

2. Communication WG: responsible for monitoring the email created to receive and meet demands, questions and complaints from nursing workers and for monitoring the Committee Instagram, as well as producing and disseminating materials for quick and scientific quality information for workers. TSGs were formed, consisting of nursing experts, for the elaboration of the response to the workers, and also of educational material. In addition to producing educational material, this WG publishes materials produced by other bodies or entities, as long as they are in line with the purpose of the Committee. The TSGs linked to the Communication WG are: Mental Health, Biosafety, Ethical Issues and Professional Registration, Labor Rights, Patient Regulation, Primary Health Care and Nursing Care for Women, People with Sickle Cell Disease and other Vulnerable Groups to COVID-19. In addition, the Communication WG has the support of creative sectors from Coren Bahia, Seeb and the Center for Learning Technologies and Knowledge in Health at UFBA.

The Communication WG also elaborates public notes and documents to the authorities with structural proposals, and without them it is understood that coping with the pandemic will not succeed, such as the strengthening of SUS, including the suspension of the financial asphyxia measures to which it is subjected and the improvement of working conditions for all who work in the health field, among others.

The Communication WG created workflows, one of which was specific for responding to emails received from workers (figure 1). For the organization of the work process, shifts were fulfilled by members of the WG.

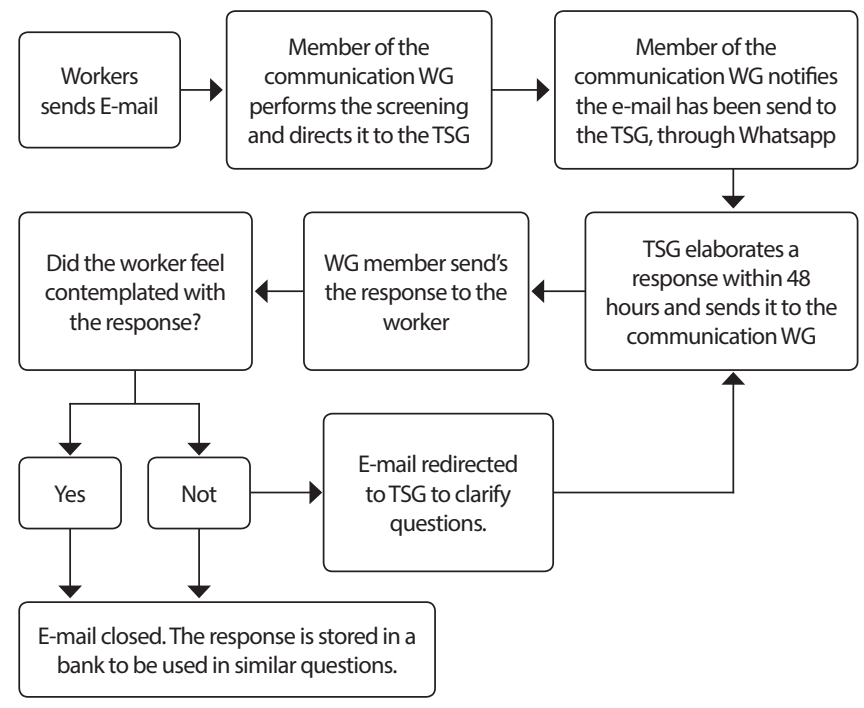

Note: Working Groups (WG); Technical Support Groups (TSG)

Figure 1 - Workflow of the Communication Working Group and the Technical Support Groups to respond emails received from nursing workers

3. WG for the Review of Health Units Contingency Plans: created based on the demand of the Municipal Health Secretary of the city of Salvador, which determined that service managers were having difficulties in formulating their contingency plans. This WG advises the unit managers in the preparation of contingency plans and reviews the flows and protocols created by the Municipal Health Secretary.
4. WG of Support to Workers in Long-Term Institutions (LTI): created from the demand of the State Health Secretary of Bahia (Sesab), which found the insufficiency of supporters in its staff for the specific guidance of LTI workers, as they are in direct contact with one of the vulnerable groups to the Coronavirus. Bahia has $150 \mathrm{LTI}$ and the members of this WG act as temporary reference techniques during the pandemic, providing guidance and passing on information from Sesab.

5. External Action WG: formed preferably by young, single people, with no comorbidities and who do not share their home with older adults or children. They visit health services to inspect the health and safety conditions of workers.

6. Epidemiology WG: responsible for the daily production of epidemiological bulletins and for monitoring cases of COVID-19 in nursing workers, using an online form. This WG tracks and monitors cases of coronavirus contamination among nursing workers, in order to identify the services in which the highest levels of contamination are occurring and their circumstances. The data will guide the actions of health authorities in preventing new cases of contamination in workers.

\section{Impact of the Committee actions}

The described impacts are related to the period of validity of the Committee and show the importance of the actions developed to properly cope with COVID-19 by nursing workers.

The CG held meetings with the managers of the Municipal Health Secretary from Salvador and the State Health Secretary from the State of Bahia to identify the work demands that could be supported by the Committee. The actions agreed with these managers were distributed to the WG. A meeting was also held with the State Public Ministry and the Public Ministry of Labor, agreeing flows to send complaints about the absence or inadequacy of PPE.

Until April 29 $9^{\text {th }}, 2020$, the communication WG produced 42 pieces of communication with the workers. The pieces addressed several topics, such as good practices when leaving and returning to the service, PPE, results of meetings and visits, technical notes, support messages, among others.

Of the 55 emails received from workers until April 30, complaints about the absence of PPE predominated (35\%), as shown in Figure 2.

All complaints received were sent to the State Public Ministry and the Public Ministry of Labor, according to the agreed flowchart, for the verification and other appropriate measures.

This WG also produced two public notes. The first note was about the statement by the President, on March $24^{\text {th }}$, which minimized the pandemic and WHO recommendations. The second note addressed Provisional Measure 927/2020, which extends the working hours and reduces rest time for health workers.

The WG of Health Units Contingency Plans Review is advising 90 of the 150 health units in Salvador in the production of contingency plans. Out of the 90 units, 50 had not yet elaborated their plans, as they had several questions, which are being clarified by this WG.

The WG of Support to Workers in Long-Term Institutions (LTI) is conducting a survey in all $150 \mathrm{LTI}$ in Bahia on health conditions, number of older adults, nursing workers and infrastructure needs, inputs and logistics. Therefore, contributing to guide the actions of SESAB and the WG. 


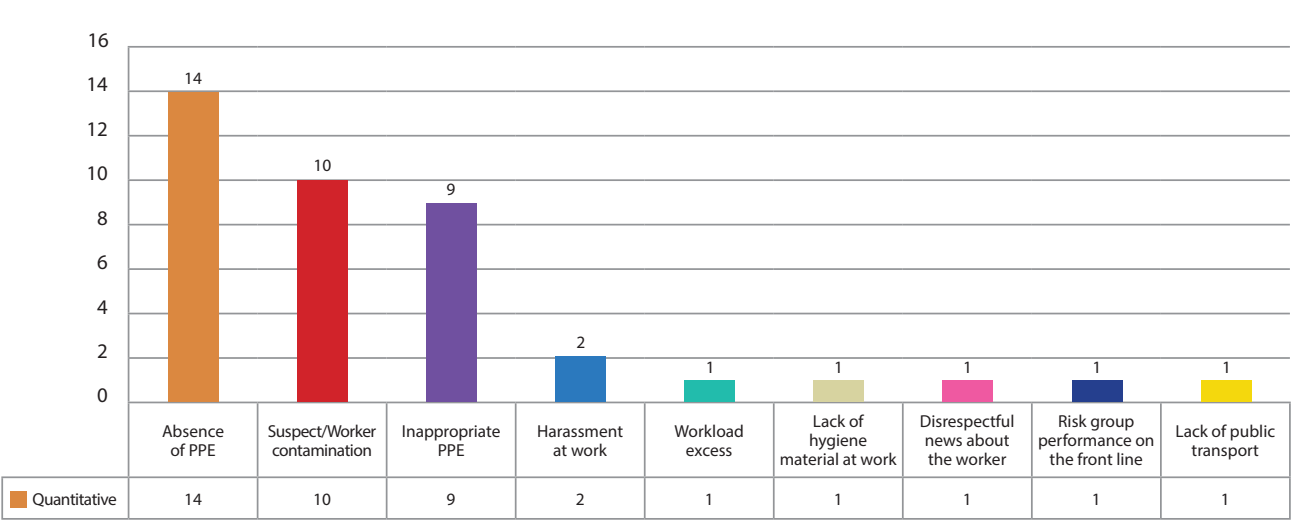

Source: Communication WG. Elaboration: Professor Dr. Ana Carla Carvalho Coelho.

Figure 2 - Number of complaints sent by nursing workers to the Committee, until April 30 $0^{\text {th }}, 2020$, Salvador, Bahia, Brazil
Contributions to the area of nursing, health or public policy

It is considered that the implementation of committees in other Brazilian states will expand support for nursing workers. The identification of demands, questions and cases of contamination of the workers subsidize actions for safe assistance. In addition, the political and technical ability of the entities and bodies
The Epidemiology WG, until April 29 ${ }^{\text {th }}, 2020$, produced 51 cards with the synthesis of epidemiological data on COVID-19 in Bahia, Brazil and other countries, as well as 10 cards that convey messages that emphasize the value of nursing workers performance on the front line of coping with coronavirus. In addition, this WG prepared an online questionnaire, on Google (https://forms.gle/2DNTLcvRRAzTRQfF8), for monitoring suspected and confirmed cases of COVID-19 in nursing workers in the State of Bahia. This questionnaire is widely disseminated through the Committee social media, with presentation folders and text messages. The instrument can be replied by nursing workers, their manager or family members and it allows us to know the possible source of contamination and in what type of service and professional category the greatest number of COVID-19 cases is occurring.

Monitoring began on April $3^{\text {rd }}, 2020$, and by 3pm on April $29^{\text {th }}$, 2020, 140 questionnaires were received. Among them, 15 were replied repeatedly, with a total of 125 valid cases considered. In the partial follow-up of these cases, 31 cases were discarded, 35 were confirmed and 59 continue to be monitored as suspected cases. Data analysis is continuously processed and directed, thus, concentrating the Committee efforts for proper control of COVID-19 among nursing workers.

The entire production of educational and epidemiological material carried out by the Communication and Epidemiology WG is considered essential, since by the principles of health education, nurses also play a fundamental role in mediating information on disease prevention and reducing dissemination of false information about the pandemic ${ }^{8}$, especially those ones spread in the media and in communication applications.

The External Action WG visited a total of 13 hospitals until May $28^{\text {th }}, 2020$, three Emergency Care Units, SAMU Salvador bases and two health centers that showed the highest number of complaints sent by workers to the Committee. Some of the visits were carried out along with the Public Ministry of Labor, the State Reference Center for Occupational Health and the Reference Center for Occupational Health. During the visits, the complaints were investigated, evidence was collected to send to the Public Ministry of Labor and guidance material on the use of PPE was distributed to the workers. involved is strengthened, which is useful for the struggles of workers after the pandemic.

The Committee reported experience refers to two months of its existence and its social and political impact can be seen. Among the social impacts on health, online monitoring of suspected and confirmed cases of infection among the workers stands out, which allows the assessment of safety and health conditions at work. The telephone monitoring of the health condition and the presence of symptoms of Covid-19 in professionals and older adults of LTI corroborates for the identification and establishment of prevention and control measures for infections, such as the provision of flu vaccines made for them. The inspections carried out in the health services have made it possible to identify health and safety conditions on the site, providing subsidies for actions with the Public Ministry of Labor. As for the political impact on nursing, there is a greater visibility among the workers of the organizations that composes the Committee and the recognition of health and judicial authorities for the work done, as well as the need for proper working conditions, such as the partnership with the Public Ministry of Labor and the State Health Secretary of Bahia.

\section{Limitations of the study}

This is an experience report in a concrete context. The reproduction of this experience may not be effective in other settings if entities and organizations in the nursing area do not build a strong political partner. The results change very quickly, due to the dynamics of the pandemic.

\section{FINAL CONSIDERATIONS}

The experience of the constitution of the Nursing Committee for Coping with COVID-19 in the state of Bahia is positive from its actions and reinforces that in the nursing area, traversed by the social and technical division of work, political articulation and aggregation must not be ignored in any context. It is considered that the results of the Committee work are contributing to guide, support, value and defend nurses, nursing technicians and assistants in coping with the COVID-19 pandemic. 
In the context of the deconstruction and reconstruction of social and economic paradigms, which can be seen in the postpandemic context of COVID-19 and which will certainly have an impact on the world of work, experiences like this, in which there is interconnection of social actors, may indicate the way to be followed so that nursing professionals can overcome social marginality, reaching the political agenda for their demands for wage regulation, working hours, proper rest and respect for staff sizing.

\section{REFERENCES}

1. Pan American Health Organization (PAHO). WHO declares public health emergency of international importance due to new coronavirus outbreak[Internet] 2020 [cited 202001 Apr]. Available from: https://www.paho.org/bra/index.php?option=com_content\&view=article\&id=6100:omsdeclara-emergencia-de-saude-publica-de-importancia-internacional-em-relacao-a-novo-coronavirus\&ltemid=812

2. Abramo L, Cecchini S, Ullmann H. Enfrentar las desigualdades en salud en América Latina: el rol de la protección social. Ciênc Saúde Coletiva. 2020;25(5):1587-98. doi: 10.1590/1413-81232020255.32802019

3. Horton R. Covid-19 in Brazil:"So what?". Lancet. 2020;395:1461. doi: 10.1016/S0140-6736(20)31095-3

4. Presidência da República (BR). Casa Civil. Subchefia para Assuntos Jurídicos. Emenda Constitucional n 95 , de 15 de Dezembro de 2016 . Altera o Ato das Disposições Constitucionais Transitórias, para instituir o Novo Regime Fiscal, e dá outras providências. Diário Oficial da União [Internet]. Seção 1.16/12/2016[cited 2020 Apr 15]. Página 2. Available from: http://pesquisa.in.gov.br/imprensa/jsp/visualiza/index.jsp?jornal=1\&pagina=2\&d ata $=16 / 12 / 2016$

5. Choi KR, Skrine JK, Logsdon MC. Nursing and the Novel Coronavirus: Risks and Responsibilities in a Global Outbreak. J Adv Nurs.2020. doi:10.1111/jan.14369

6. Dimple DR, Meng HL, Sophia A, Natasha B, Swee CQ. The many estimates of the COVID-19 case fatality rate. Lancet Infect Dis. 2020; 20:4733099. doi: 10.1016/ S1473-3099(20)30244-9

7. Araújo-dos-Santos T, Silva-Santos H, Silva MN, Coelho ACC, Pires CGS, Melo CMM. Job insecurity among nurses, nursing technicians and nursing aides in public hospitals. Rev Esc Enferm USP. 2018;52:e03411. doi: 10.1590/s1980-220x2017050503411

8. Conselho Federal de Enfermagem. Brazil has 30 deaths in Nursing by Covid-19 and 4 thousand retired professionals[Internet] 2020 [cited 202015 Apr]. Available from: http://www.cofen.gov.br/brasil-tem-30-mortes-na-enfermagem-por-covid-19-e-4-mil-profissionaisafastados_79198.html

9. World Health Organization (WHO). State of the world's nursing 2020: investing in education, jobs and leadership[Internet]. 2020 [cited 2020 $14 \mathrm{Apr}$. Available from: https://www.who.int/publications-detail/nursing-report-2020

10. Machado MH, Oliveira E, Lemos W, Lacerda WF, Aguiar Filho W, Wermelinger M, et al. Mercado de trabalho da enfermagem: aspectos gerais. Enferm Foco [Internet]. 2016 [cited 202010 Apr];7(ESP):35-62. Available from: http://revista.cofen.gov.br/index.php/enfermagem/article/view/691/301 